\title{
DVA SÚBORY ARCHEOLOGICKÝCH NÁLEZOV Z OBCE ZEMPLÍN¹
}

\author{
Martin Pristáš
}

DOI: https://doi.org/10.31577/szausav.2019.suppl.1.24

Keywords: Eastern Slovakia, Zemplín, find, Late La Tène Period, painted pottery

\section{Two assemblages of archaeological artefacts from the village of Zemplín}

The research activities of the Monuments Board of the Slovak Republic in Zemplín resulted in the acquisition of two assemblages of archaeological artefacts retrieved during various construction works performed in the village in the past. The first assemblage consists of four clay bottles from the Late La Téne Period, of which one was found intact, while the other three required restoration. The second set is a larger one, consisting of prehistoric pottery, technical pottery, fragments of decorated pottery from the Late La Téne Period, and fragments of pottery from the Late Medieval or Early Modern Period. The most remarkable find of the second assemblage is a storage vessel with plastic decoration and a clay lid.

Obec Zemplín je jednou z najdôležitejších archeologických lokalít Slovenska nadregionálneho významu. Je to dané mimoriadne výhodnou geografickou polohou obce v južnej časti Východoslovenskej nížiny na pravom brehu rieky Bodrog, kde sa mierne zvažujú východné úpätia Zemplínskych vrchov. Starému meandru Bodrogu dominuje skalnatý kopec pokrytý naviatymi pieskami s názvom Hradisko (Várhegy; obr. 1). Ned’aleko v južnom smere od tejto vyvýšeniny sa v minulosti nachádzal riečny prievoz. To spravilo z daného miesta významnú križovatku pravekých a stredovekých ciest.

Prvé archeologické nálezy z obce začali

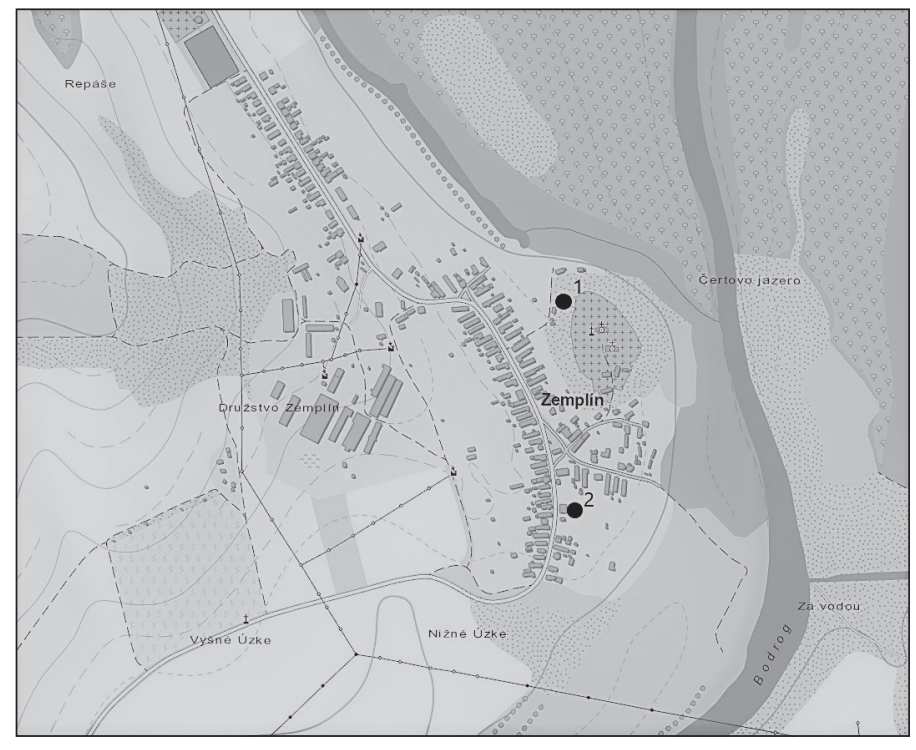

Obr. 1. Zemplín, situačný plán obce. 1 - parcela 15/1; 2 - obecný úrad. Autor M. Pristáš. Zdroj: http://zbgis.skgeodesy.sk. zhromažd’ovat' už osvietenskí učenci, o čom nás prvýkrát informuje zemplínsky notár A. Szirmay de Szirma (1747 Prešov1812 Svinice) vo svojich prácach o historických, topografických a politických poznatkoch stolice Zemplínskej. Založenie osady pripisuje Rimanom, ked’že sa v obci zvyknú nájst' početné staršie vyspelé predmety a mince. Sám spomína, že vlastní vo svojej zbierke striebornú mincu zo Zemplína s motívom vtáka (Szirmay 2004, 58). Za jednu $\mathrm{z}$ najzaujímavejších pamiatok $\mathrm{v}$ regióne považoval Zemplín aj J. Visegrády profesor histórie na piaristickom gymnáziu v meste Sátoraljaújhely, ktorý začiatkom 20. stor. so svojimi študentmi navštívil viaceré lokality v tejto oblasti (Luštíková/Miroššayová 2009, 159). Dejiny moderného výskumu v obci Zemplín začínajú 27. 7. 1931 príchodom Š. Janšáka (1886-1972), ktorý mapoval praveké náleziska východného Slovenska.

\footnotetext{
Cielom tohto príspevku nie je vyčerpávajúce spracovanie týchto nálezov, ani ich vyhodnotenie v rámci širšieho regiónu, ale hlavne sprístupnenie odbornej verejnosti.
} 
Od roku 1953 pokračujú vo výskume obce pracovníci AÚ SAV v Košiciach K. Andel, B. Benadik, V. Budinský-Krička, M. Lamiová, E. Miroššayová, D. Čaplovič a další. Zhruba 87 rokov moderného archeologického výskumu v obci nám prinieslo významné archeologické nálezy od doby kamennej až po novovek (Chovanec 2004; Lamiová 1993). Postupne tak vznikala mapa archeologických lokalít v katastri obce, ktoré sa tiahnu prakticky súvisle po pravom brehu rieky Bodrog na východnom svahu pohoria Zemplínske vrchy. Od roku 2014 vedie systematický vedecký archeologický výskum v obci aj Pamiatkový úrad SR. Výskum je zameraný na vývoj komitátneho a župného centra a v súčasnosti prebieha v severnej časti opevnenia polohy Hradisko (Pristáš 2018, 47-56).

Počas výskumných sezón sa nám podarilo získat aj dva súbory archeologických nálezov, náhodne objavených v katastri obce počas rôznych prác v minulosti.

Prvý súbor pochádza od obyvatela domu 183 p. Rostáša, ktorý ho našiel počas výkopových prác vedla tohto domu na parcele číslo 15/12 pred rokom 2015.

Súbor tvorí dokopy 25 predmetov. Samostatný artefakt je v úplnosti zachovaná nádoba z okruhu neskorolaténskej malovanej keramiky a jeden $\mathrm{v}$ ruke modelovaný hlinený predmet. Zvyšok súboru tvoria črepy neskorolaténskej malovanej keramiky, z ktorých sa podarilo zrekonštruovat d'alšie tri neúplné nádoby.

\section{SÚBOR 1}

\section{Opis nálezov}

1. Celá nádoba, $v$ úplnosti zachovaný exemplár typologicky zaraditelný medzi malé vázovité/flašovité nádoby skupiny II (Čambal 2004, 18), s horným okrajom lievikovito vytiahnutým nahor, úzkym hrdlom, vajcovitým bruchom s maximálnym obvodom $\mathrm{v}$ dolnej tretine nádoby, ktoré plynulo prechádza do neodsadeného, jemne do vnútra nádoby vypuklého dna. Nádoba je vyhotovená na hrnčiarskom kruhu z kvalitnej, jemne plavenej hliny. Výpal má svetlohnedú farbu, povrch nádoby je kvalitne opracovaný a v hornej časti vydutia plošne malovaný engobami v pásoch. Ústie, hrdlo a časte tela (plece) v hrúbke $44 \mathrm{~mm}$ pokrýva čierna malba, nasleduje približne $48 \mathrm{~mm}$ hrubá červená pasáž, ktorú zdola ohraničuje opät čierny približne 11 až $13 \mathrm{~mm}$ hrubý pás. Čierne pásy sú dodatočne ozdobené rytou závitnicou, červeno malovaná plocha je $\mathrm{v}$ hornej časti zdobená vleštovanou vlnovkou $\mathrm{v}$ troch vodorovných pásoch a $\mathrm{v}$ dolnej časti vleštovanými zrkadlovo ukladanými zväzkami piatich zvislých šikmo bežiacich liniek. Zhruba $1 / 5$ plochy nádoby pokrýva čierny flak, ktorý zrejme svedčí o dodatočnom styku s ohňom. Na nádobe sú badatelné stopy po neodbornej manipulácii počas objavu. Rozmery: vonkajší priemer ústia je $42 \mathrm{~mm}$, vonkajšś priemer hrdla $32 \mathrm{~mm}$, najväčší vonkajší priemer brucha $125 \mathrm{~mm}$, výška $120 \mathrm{~mm}$ (tab. I: 1).

2. Neúplná nádoba zrekonštruovaná zo šiestich úlomkov taktiež spadá do skupiny vázovitých/flašovitých na kruhu z jemne plavenej hliny vyhotovených nádob s úzkym hrdlom a ústim horného okraja lievikovito vytiahnutým nahor. Telo je baňaté s maximálnym vydutím v strednej časti. Dno odsadené a jemne vypuklé do vnútra s jemnou ryhou v tvare kruhu. Spôsob malovanej výzdoby je zhodný s predošlým exemplárom: ústie, hrdlo a plecia nádoby čierne, taktiež cca $12 \mathrm{~mm}$ hrubý pás v oblasti maximálneho vydutia. Oblast̉ medzi nimi je pokrytá svetločervenou engobou, v ktorej je vidiet vleštované zvislé šikmo bežiace zväzky čiar. Dolná čast nádoby opät bez výzdoby. Výpal kvalitný, zvonivý, svetlooranžový. Rozmery: vonkajší priemer ústia je $52 \mathrm{~mm}$, vonkajší priemer hrdla $36 \mathrm{~mm}$, priemer dna $57 \mathrm{~mm}$, najväčší vonkajší priemer brucha ani výška sa nedajú spolahlivo určit (tab. I: 3).

3. Pät kusov úlomkov sa podarilo priradit klasickému tvaru flašovitej nádoby typu II/3 (Čambal 2004, 203) $\mathrm{s}$ baňatým bruchom, úzkym hrdlom a von vytiahnutým ústím horného okraja. Dno je úzke a odsadené. Nádoba je vyhotovená na kruhu z jemne plavenej hliny, výpal kvalitný, zvonivý, svetlooranžový. Povrch starostlivo vyhladený s plošnou malovanou výzdobou v pásoch $v$ hornej časti nádoby. Ústie, hrdlo a plece nádoby je hnedé, hornú čast brucha pokrýva čierny pás s vleštovanými vertikálnymi šikmými zväzkami čiar. Rozmery: vonkajší priemer ústia je $62 \mathrm{~mm}$, vonkajší priemer hrdla $39 \mathrm{~mm}$, priemer dna $53 \mathrm{~mm}$, najväčší vonkajší priemer brucha ani výška sa nedajú spolahlivo určit', napriek tomu vieme tvar nádoby pomerne spolahlivo zrekonštruovat' (tab. I: 5).

4. Medzi flašovité/vázovité nádoby typu II/1 je možné zaradit neúplnú nádobu, z ktorej sa dochovali dva väčšie črepy. Z nich sa ale dá v celku presne vyčítat, že išlo o nádobu s hrdlom o niečo širším ako majú predchádzajúce a baňatým telom. Tvar a rozmery ústia ani dna sa nedochovali. Engoba i malba pokrýva len hornú čast tela. Hrdlo a stred brucha pokrýva čierny pás, medzi nimi červená plocha s niekolkými horizontálnymi riadkami vleštovanej vlnovky. Nádoba je zhotovená na hrnčiarskom kruhu z jemne plavenej hliny, výpal kvalitný, zvonivý, svetlooranžový. Aj tu je prítomná na tele čierna škvrna po sekundárnom styku s ohňom. Rozmery nie je možné presne určit (tab. I: 7).

5. Z dalších keramických fragmentov sa už nepodarilo zrekonštruovat ucelenejšie nádoby. Fragment hrdla (tab. II: 5) a tela (tab. I: 8) môže pochádzat’ z väčšej vázovitej malovanej nádoby, podobne i hrubšie ústie hrdla (tab. I: 2). Fragment dna (tab. II: 6) je síce nezdobený, avšak charakter lepšie dochovaných nádob ukazuje, že je určite tiež súčastou

\footnotetext{
Vlastník domu aj pozemku je obec Zemplín.
} 
skupiny neskorolaténskej mal’ovanej keramiky. Zvyšné fragmenty už do tejto skupiny nepatria. Sú zhotovené na hrnčiarskom kruhu, tenkostenné a kvalitne vypálené. Stopy po výzdobe sa nezachovali (tab. I: 6; II: 4).

6. Súbor obsahuje ešte jeden hlinený artefakt, ktorý ale nepatrí medzi keramický riad. Je vyrobený modelovaním v ruke do tvaru pripomínajúceho pečatidlo: valček z hliny bol z jednej strany roztlačený, aby vznikla rozšírená elipsovitá rovná plošinka. Valcovitá čast̉ bola priečne perforovaná a následne bol predmet vypálený. Rozšírená čast’ je hladučká a podobne ako niektoré vyššie popísané nádoby ju pokrýva čierna škvrna po dodatočnom styku s ohňom. Môže íst’ o predmet využívaný pri remeselnej výrobe napríklad ako „leštidlo“33 (tab. II: 1).

\section{Analýza}

Na nálezy neskorolaténskej malovanej keramiky v obci Zemplín a okolí ako prvý upozornil pracovník ÁU SAV K. Andel ktorý ich získal počas svojej prospekčnej činnosti v rokoch 1953 a 1954 (Andel 1955). Na základe toho začal sondážny výskum pod vedením B. Benadika, ktorý tento druh nálezov začal postupne vyhodnocovat' (Benadik 1957; 1965). Postupne pribúdali takmer počas všetkých výskumných i nevýskumných aktivít v obci (Luštíková/Miroššayová 2009, 160; Miroššayová/Čaplovič 1991, 118; Pristáš 2018, obr. 5: 5). V rámci Slovenska bol tento druh materiálnej kultúry podrobne spracovaný v rámci nálezov z výskumu akropoly neskorolaténskeho oppida, ktoré sa rozprestieralo na hradnom vrchu v Bratislave a spadá do stupňov LTD1 a LTD2 (Čambal 2004).

Druhý súbor bol „objavený“ v sklade obecného úradu v škatuli s nápisom „Vol'by 2006“. Ide takmer výlučne o zlomky keramického riadu prevažne pravekého rázu.

\section{SÚBOR 2}

\section{Opis nálezov}

1. Asi najväčšiu pozornost púta čiastočne zrekonštruovaná ${ }^{5}$ nádoba zásobnicového tvaru so širokým hrdlom a jednoducho von vytiahnutým ústim horného okraja. Ide o hrubostennú v ruke modelovanú nádobu s dodatočne hladeným vonkajším povrchom zrejme chumáčom suchej trávy, o čom svedčia miniatúrne nesúmerné rôznym smerom bežiace ryhy viditelné na väčšej časti tela. Povrch i celkový tvar však ostáva značne členitý až hrubý. Výpal je málo kvalitný, miestami je vidiet povrchové praskliny. Farebnost̉ na vonkajšej strane je nejednotná. V hornej časti prevládajú odtiene okrovo žltej, smerom nadol nádoba tmavne a pribúdajú svetlé škvrny. Tmavé flaky sa však vyskytujú sporadicky na celej dochovanej ploche nádoby. Vnútro je zadymené. Výzdoba je plastická, umiestnená na nevýrazných pleciach nádoby. Ide o kombináciu polkruhu s oblúkovo von zahnutými koncami a plastického výčnelku v strede. Stav dochovania nám umožňuje uviest len približné rozmery nádoby: priemer ústia asi $300 \mathrm{~mm}$, max. priemer približne $380 \mathrm{~mm}$, priemer dna okolo $180 \mathrm{~mm}$, výška asi $460 \mathrm{~mm}$ (tab. III: 1).

2. Grafitový okrúhly praslen vytvorený sekundárne z črepu, zrejme klasického situlovitého hrnca s rytou hrebeňovou výzdobou opracovaním hrán a prevítaním stredového otvoru. Rozmery: max. priemer $45 \mathrm{~mm}$, priemer otvoru $15 \mathrm{~mm}$, hrúbka asi $10 \mathrm{~mm}$ (tab. IV: 1).

3. Hrubostenný technický výrobok vypálený z hliny, svetločervenej farby, tvarom pripomínajúci misku. Telo nádoby je celoplošne perforované menšími otvormi s priemerom 3 až $4 \mathrm{~mm}$, okraj jednoducho ukončený. Rozmery: max. priemer $143 \mathrm{~mm}$, priemer "dna“ $98 \mathrm{~mm}$, výška $91 \mathrm{~mm}$ (tab. IV: 2).

4. Kónická misa s jemne von vytiahnutým zosilneným horným okrajom. Zachovaná fragmentárne v siedmich kusoch črepov z tela a horného okraja. Nádoba je vyrobená na hrnčiarskom kruhu zo sivej jemne zrnitej hliny. Povrch v hornej časti je svetlosivý, postupne prechádza do tmavosivej, vyhladený do leskla. V oblasti jemne odsadeného hrdla je nádoba perforovaná dvoma menšími otvormi nad sebou vo vzdialenosti $13 \mathrm{~mm}$ (tab. II: 7).

5. Torzo hrubostennej nádoby vyrobenej v ruke zo zrnitého materiálu, s drsným povrchom svetločervenej farby. Ústie mierne vytiahnuté von, dno od tela hrubo odsadené. Výzdobu tvorí kombinácia plastických gombíkovitých výčnelkov spájaných zahnutou líniou vtláčaných jamiek (tab. IV: 3).

6. Torzo dolnej časti a dna hrubostennej v ruke modelovanej nádoby vyrobenej zo zrnitého materiálu. Vonkajš́ povrch je drsný, farba tela je okrová žltá bez dochovanej výzdoby. Vnútro je sivé a drsné. Dno nádoby je tmavosivé, velmi hrubo opracované so stopami po textílii v otlačkoch po prstoch, čo svedčí o spôsobe práce hrnčiara. Priemer dna je $156 \mathrm{~mm}$ (tab. IV: 4).

7. Torzo dolnej časti a dna hrubostennej v ruke robenej nádoby. Je vyrobená z vel’mi zrnitej sivej hliny. Vonkajší povrch je svetlosivý, drsný, bez dochovanej výzdoby. Vnútorný povrch je čierny. Prechod z tela ku dnu je odsadený so stopami modelovania. Priemer dna je $80 \mathrm{~mm}$ (tab. IV: 5).

3 Za konzultácie d’akujeme pracovníkom košickej pobočky AÚ SAV E. Miroššayovej a L. Olexovi.

4 Na nálezy nás upozornil súčasný starosta obce Zemplín M. Takács.

5 Okrem črepov, ktoré sa nám podarilo zlepit do jedeného celoku, obsahuje súbor ešte osem kusov črepov evidentne prislúchajúcich k predmetnej nádobe. 
8. Torzo dutej nôžky. Dochované spolu s dnom nádoby, ktoré je vo vnútri vaničkové, ale zo spodnej strany rovné a nevyhladené. Dolný okraj nôžky je jednoducho vodorovne zrezaný. Nádoba bola zhotovená v ruke z jemne zrnitej hliny. Povrch je svetlej okrovej farby. Výška torza je $71 \mathrm{~mm}$ (tab. II: 2).

9. Torzo dolnej časti tela a dna. Nádoba je vyrobená v ruke zo sivého zrnitého materiálu s čiastočne odsadeným dnom. Výzdoba nedochovaná (tab. II: 3).

10. Fragment neglazovanej najskôr renesančnej kachlice s motívom rozety (tab. V: 1).

11. Horná čast̉ neskorostredovekej pokrievky (tab. V: 2).

12. Črepy nádob z okruhu neskorolaténskej malovanej keramiky. Malované striedaním červených a čiernych pásov s vleštovanou lineárnou výzdobou (tab. V: 3, 5) alebo striedaním červených a bielych pásov bez d’alšej výzdoby (tab. V: $4,6,7)$.

13. Súbor obsahuje ešte množstvo drobných úlomkov zväčša dobre vypálenej, tenkostennej, kvalitnej malovanej i nemal'ovanej keramiky, ktoré sme do tabuliek nezarad'ovali.

\section{Analýza}

1. Zlomky podobnej hrubostennej nádoby s podobným plastickým motívom zo Zemplína B. Benadik zaradil medzi pamiatky dáckeho hrnčiarstva (Benadik 1965, 82).

2. Na sídliskách doby laténskej ide o častý jav (Čambal 2004, 30; Resutík 2007, 115).

3. Pomerne dobre rekonštruovatelný poklop na pahrebu. ${ }^{6}$ Typickým znakom je centrálny väčśí otvor na "dne" nádoby, ktorý je v tomto prípade vlastne hornou častou, slúži na odvod dymu a reguláciu prívodu kyslíka. Bolo tak možné udržiavat žeravé uhlíky pre potreby fungovania domácnosti alebo transportu. Širšej škále využitia zodpovedá i variabilita tvarov (Valentová/Šumberová 2012, 339). Najbližšia analógia zhodného tvaru sa našla počas záchranného výskumu na rekonštrukcii plynovodu v polohe Čierna zem v katastri obce Ruská (okres Trebišov) v zahíbenom objekte obsahujúcom laténsku keramiku. Avšak tento typ technickej keramiky sa nachádza aj na náleziskách zo staršej doby železnej (Kacsó 2007, 167) alebo doby rímskej (Furman 2016, 197; Varsik 2011, 14). Tri exempláre zhodného tvaru pochádzajú z oppida v Stradoniciach v stredných Čechách (ValentoválŠumberová 2012, 339, 340).

4. Ked’že sa nezachovala spodná čast' nádoby, nie je možné vylúčit, že ide o cedidlo.

5. Celkové rozmery nie je možné určit, ale kedže sa zachovali fragmenty ústia, tela s výzdobou aj okraj dna, môžeme s určitostou povedat', že tu ide o klasický príklad stredne vel'kého až vel'kého dáckeho hrnca (Luštíková 2007, tab. II: 1). Tento typ nádoby sa hojne vyskytuje medzi nálezmi z viacerých výskumov v obci Zemplín (Benadik 1965, obr. 13; Budinský-Krička/Lamiová-Schmiedlová 1990, 300; Miroššayová/Čaplovič 1991, 131).

6. Charakter nádoby je vel'mi podobný ako v prípade vyššie (bod 1) popisovaného artefaktu z tohto súboru.

8. Miskovité tvary nádob na nôžke sú bežné $\mathrm{v}$ dáckom prostredí a vyskytujú sa aj v Zemplíne (Luštíková 2007, 80). Tvarovo zhodné torzo sa našlo v hrobe 13 na žiarovom pohrebisku z obdobia keltskodáckej symbiózy v polohe Szélmalomdomb (Budinský-Krička/Lamiová-Schmiedlová 1990, 321, tab. II: 15).

\section{ZÁVER}

Oba predmetné súbory boli nájdené mimo povoleného archeologického výskumu alebo stavby a boli získané v zmysle platnej legislatívy priamo od nálezcu resp. obce. Takéto nálezy zvykneme označovat ako náhodné. $V$ oboch prípadoch však nebol zákonný postup dodržaný do takej miery, aby sme mohli nálezové okolnosti označit za optimálne. V prvom prípade súboru z parcely 15/1 vieme síce celkom presne určit miesto nálezu, avšak nálezca neskoro zaregistroval počas výkopových prác nález a evidentne čast súboru zničil. Nález neoznámil hned', ale z odstupom času, čiže priame nálezové okolnosti už zanikli. $\mathrm{V}$ prípade súboru z obecného úradu nevieme ani presné miesto nálezu a dátum nálezu vieme určit len rámcovo. Napriek tomu sa nám podarilo získat niekol'ko vel'mi zaujímavých artefaktov, ktoré vynikajú svojou ojedinelostou či stavom dochovania.

\footnotetext{
Niekedy sa stretávame aj s termínom „,vykurovadlo“.
} 
DVA SÚBORY ARCHEOLOGICKÝCH NÁLEZOV Z OBCE ZEMPLÍN

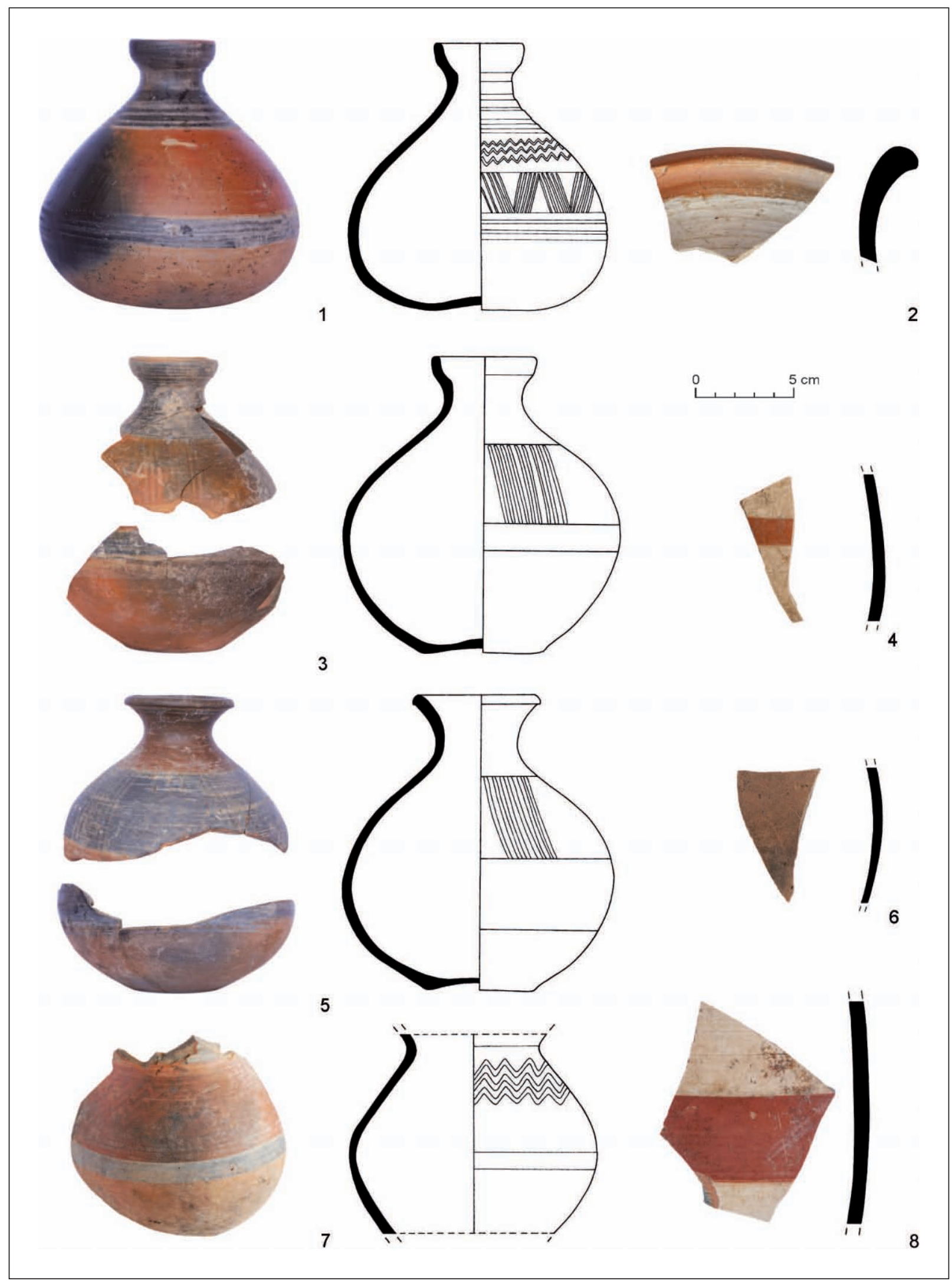

Tab. I. Zemplín, parcela 15/1. 1-5, 7, 8 - neskorolaténska mal’ovaná keramika. Foto a kresba B. Čurná Roman. 


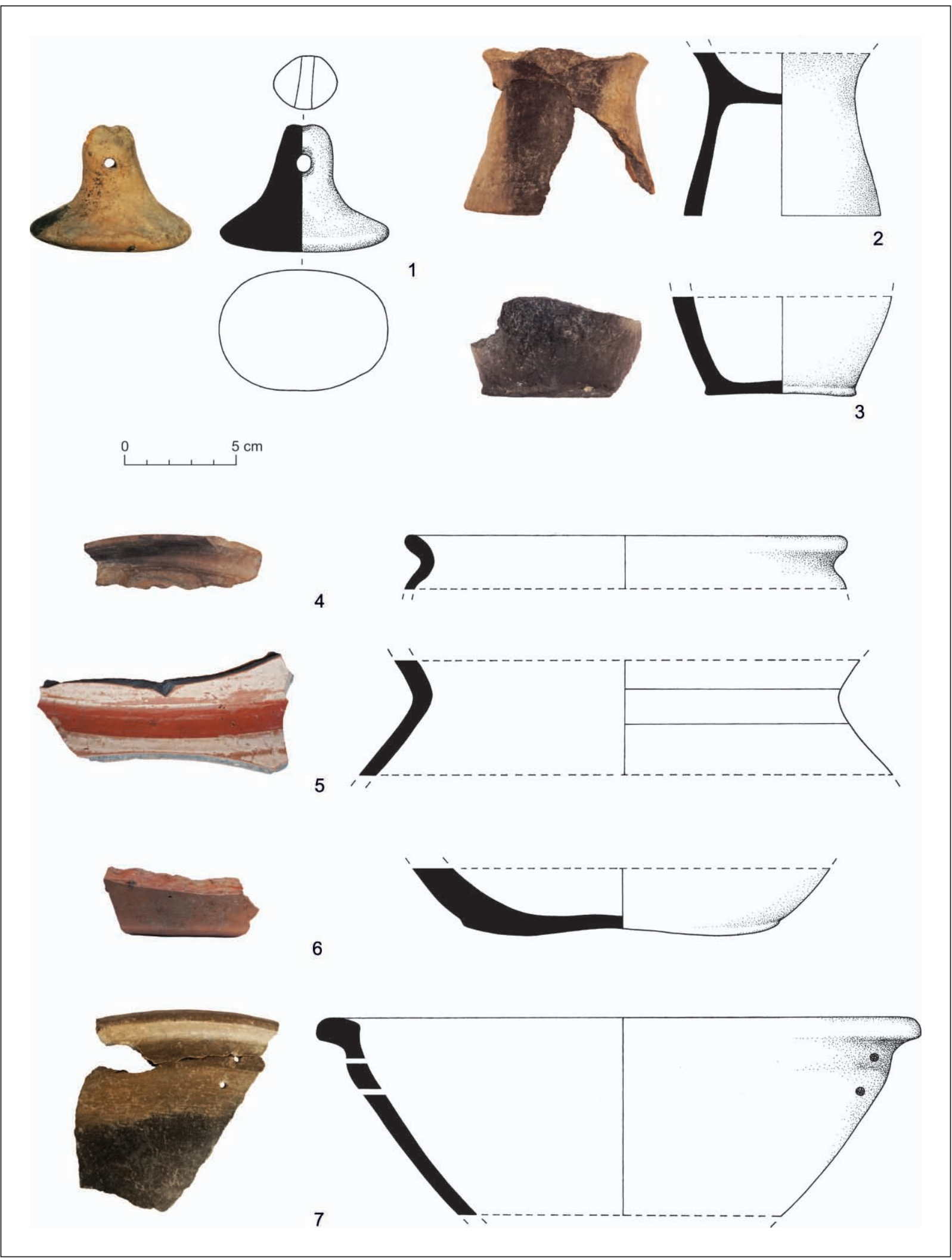

Tab. II. 1, 4-6 - Zemplín, parcela 15/1, keramika zo súboru; 2, 3, 7 - Zemplín, obecný úrad, keramika zo súboru. Foto a kresba B. Čurná Roman. 


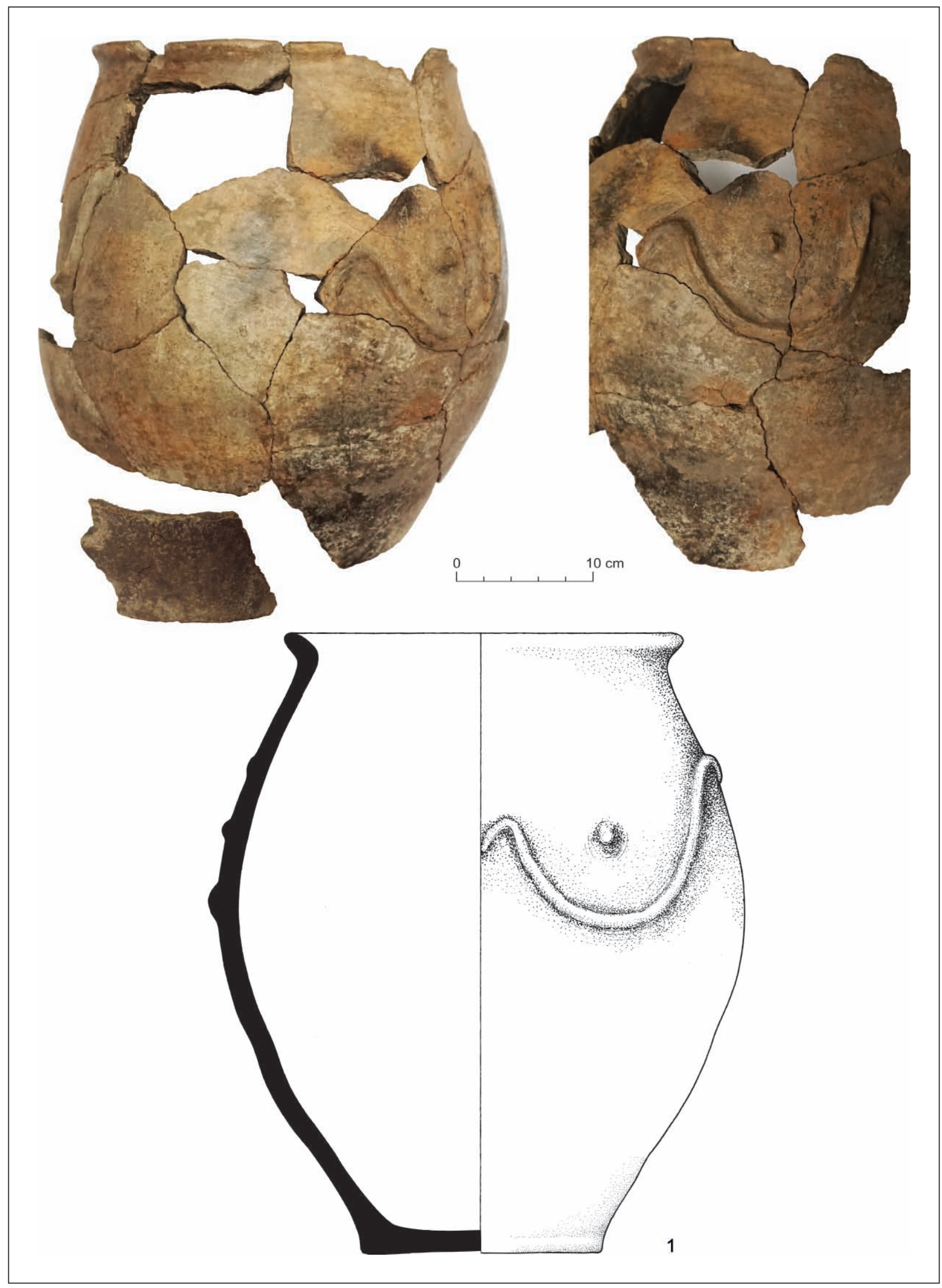

Tab. III. Zemplín, obecný úrad, väčšia nádoba zásobnicového tvaru. Foto a kresba B. Čurná Roman. 


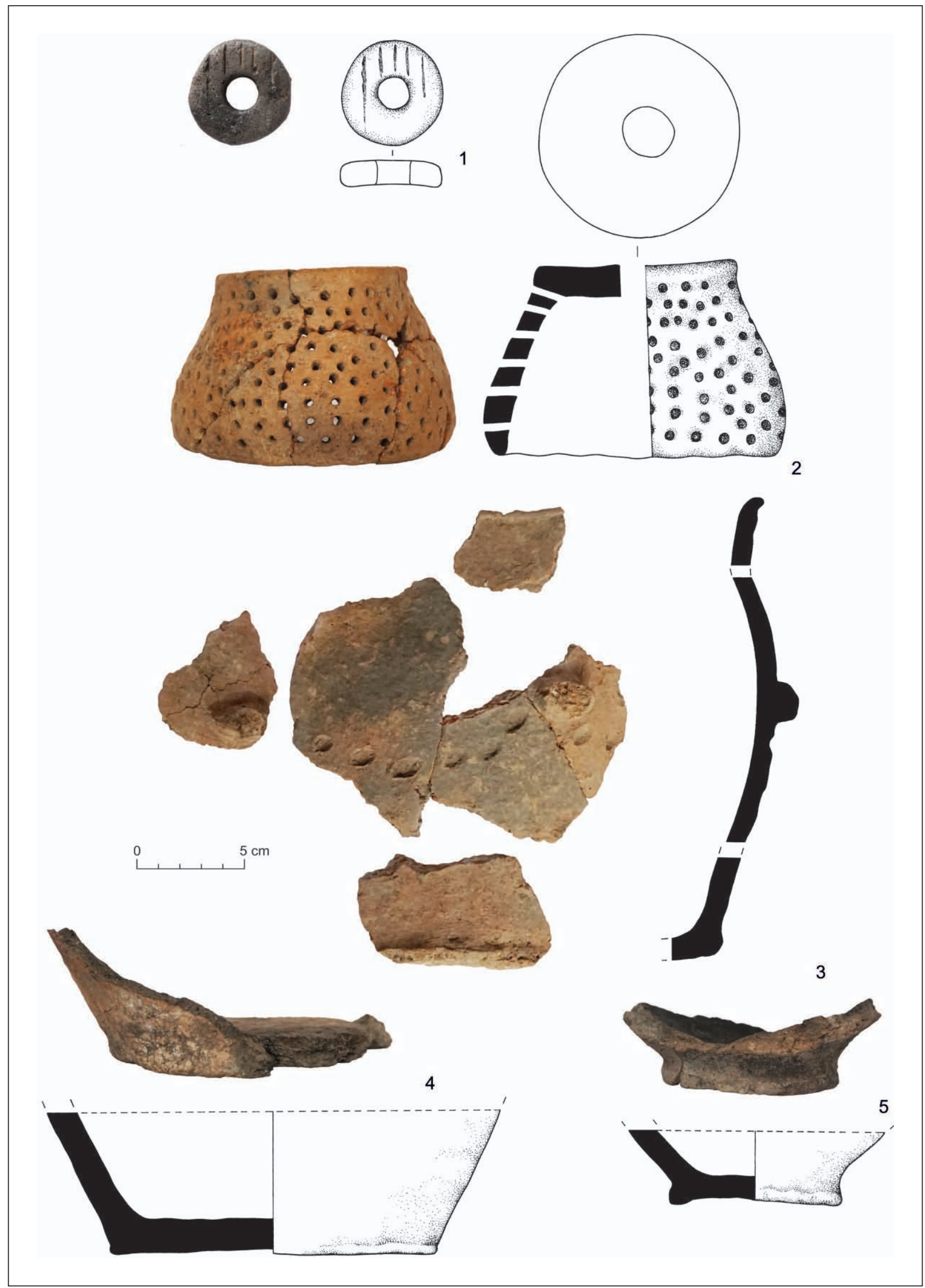

Tab. IV. Zemplín, obecný úrad, nálezy zo súboru. Foto a kresba B. Čurná Roman. 

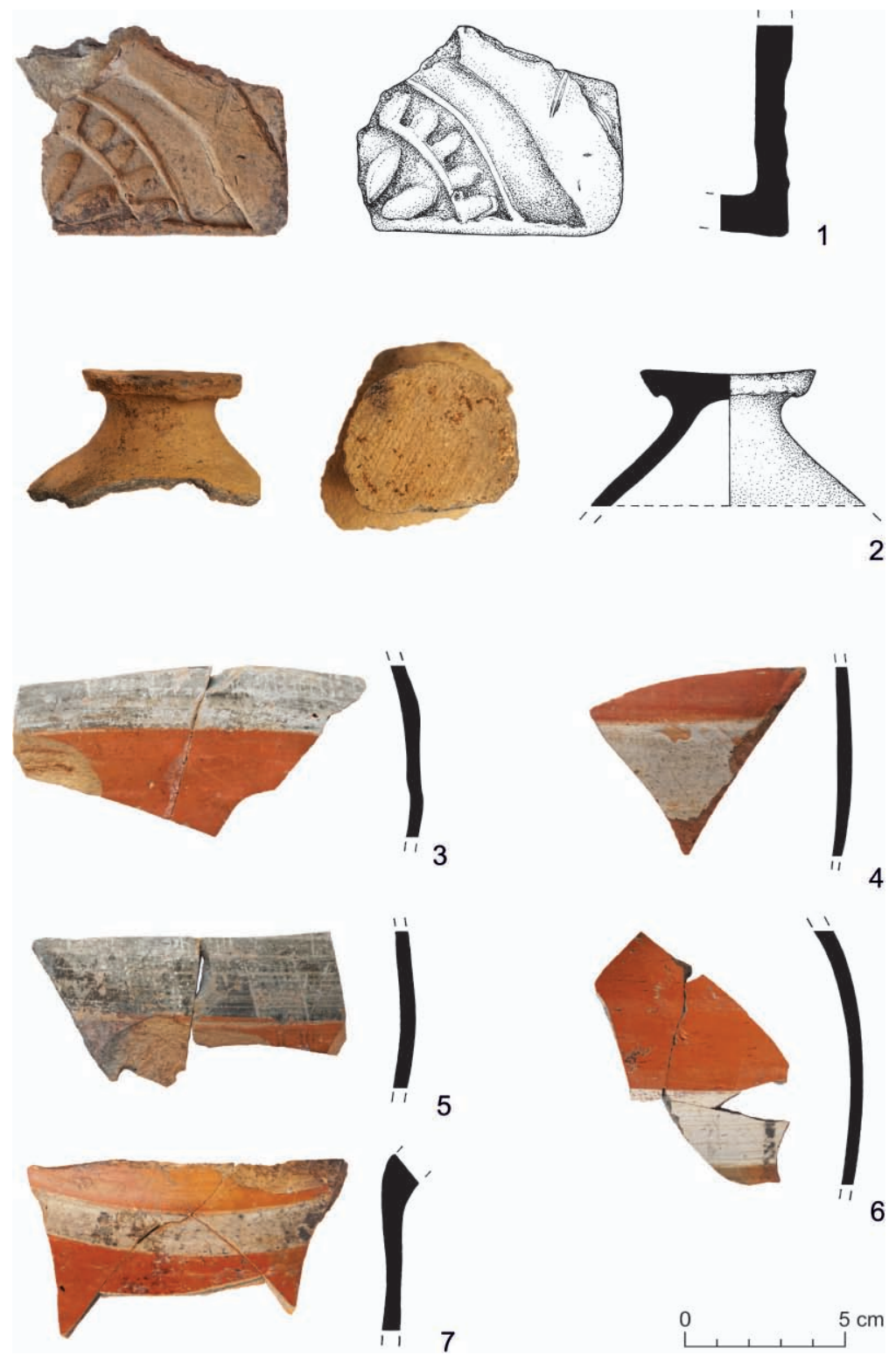

0 $5 \mathrm{~cm}$ 


\title{
LITERATÚRA
}

Andel 1955

Benadik 1957

Benadik 1965

Budinský-Krička/Lamiová-Schmiedlová 199

K. Andel: Výsledok archeologického prieskumu na zemplínsko-užskej nížine v rokoch 1953-1954. Vlastivedný sborník 1, 1955, 144-171.

B. Benadik: Výzdobné prvky na neskorolaténskej mal'ovanej keramike zo Zemplína. Študijné zvesti AÜ SAV 2, 1957, 83-86.

B. Benadik: Die spätlatenezeitliche Siedlung von Zemplín in der Ostslowakei. Germania 4, 1965, 63-91.

V. Budinský-Krička/M. Lamiová: A late $1^{\text {st }}$ century B.C.- $2^{\text {nd }}$ century A.D. cemetery at Zemplín. Slovenská archeológia 38, 1990, 245-344.

Čambal 2004

R. Čambal: Bratislavský hradný vrch - akropola neskorolaténskeho oppida. Zborník SNM. Archeológia. Supplementum 1. Bratislava 2004.

Furman 2016

Chovanec 2004

M. Furman: Opevnenia na Liptove. Žilina 2016.

J. Chovanec: Zemplín. In: L. Gačková a kol.: Archeologické dedičstvo Zemplína. Pravek až včasný stredovek. Michalovce 2004, 515-522.

Kacsó 2007

Lamiová 1993

Luštíková 2007

C. Kacsó: Hallstattzeitliche Funde in der Maramuresch. Východoslovenský pravek 8, 2007, 161-188.

M. Lamiová: Zemplín, obec s bohatou minulost’ou. Košice 1993.

L. Luštíková: Dácka keramika na území Slovenska. Východoslovenský pravek 8, 2007, 77-96.

Luštíková/Miroššayová 2009

Miroššayová/Čaplovič 1991

Pristáš 2018

Resutík 2007

Szirmay 2004

Valentová/Šumberová 2012

Varsik 2011
L. Luštíková/E. Miroššayová: Príspevok k osídleniu polohy Hradisko v Zemplíne. Východoslovenský pravek 9, 2009, 159-168.

E. Miroššayová/D. Čaplovič: Najnovšie výsledky výskumu včasnodejinného a stredovekého osídlenia v Zemplíne. Východoslovenský pravek 3, 1991, 115-132.

M. Pristáš: Archeologický výskum polohy Hradisko v obci Zemplín. Monumentorum Tutela 27, 2018, 47-56.

B. Resutík: Východné suburbium Bratislavského oppida - archeologický výskum na Hlavnom námestí 8. Zborník SNM 101. Archeológia 17, 2007, 97-120.

Anton Szirmay de Szirma: Historické, topografické a politické poznatky stolice Zemplínskej. Michalovce 2004.

J. Valentová/R. Šumberová: Keramické cedníky, poklopy a trychtýře z oppida Stradonice. Archeologické rozhledy 64, 2012, 333-346.

V. Varsik: Slovensko na hraniciach rímskej ríše. Trnava 2011.

\section{Two assemblages of archaeological artefacts from the village of Zemplín}

\author{
Martin Pristá š
}

Summary

The village of Zemplín is one of Slovakia's most important archaeological sites of trans-regional significance. Its advantageous location at the foot of the Zemplín Hills near a river crossing of the Bodrog river made it an important crossroads of prehistoric and medieval routes. The first archaeological artefacts were found in the village in the $18^{\text {th }}$ century. The Monuments Board of the Slovak Republic has conducted systematic scientific archaeological research in the village since 2014. The research is focused on the development of the comitatus and regional administration centre (referred to as "župa"), and is currently carried out in the northern part of the "Hradisko" fortification (Pristáš 2018, 47-56). During research seasons, the author also managed to acquire two assemblages of archaeological artefacts discovered in the cadastre of the village by accident during various works performed in the past. The set is from the owner of house no. $183 \mathrm{Mr}$. Rostáš who found it during digging works next to the house on land plot no. 15/1 before 2015. The set consists of 25 items. One of the items is a decorated clay bottle from the late La Téne period found in an excellent condition, and one is a hand-shaped clay item that was probably used in craft-related activities. The rest of the set consists of fragments of late La Téne painted pottery, from which three incomplete pots could be restored. The second set was "discovered" in the storage area of the municipal office. It consists almost exclusively of fragments of pottery predominantly of prehistoric origin. The most remarkable find of the assemblage is the storage vessel with 
plastic decoration and a clay lid for controlling the heat of burning coals. The artefacts are related to the pottery used by the Celts and the Dacians, who created remarkable symbiosis on the territory of the present-day village of Zemplín between the La Téne and the Roman periods (Benadik 1965; Čambal 2004; Luštíková 2007)

Fig. 1. Zemplín, situational plan of the village. 1 - land plot 15/1; 2 - municipal office. Author M. Pristáš. Source: http:// bbgis.skgeodesy.sk

Pl. I. Zemplín, land plot 15/1. 1-5, 7, 8 - late La Tène painted pottery. Photo and drawing B. Čurná Roman.

Pl. II. 1, 4-6-Zemplín, land plot 15/1; ceramic from the assemblage; 2, 3, 7 - Zemplín, municipal office, ceramic from the assemblage. Photo and drawing B. Čurná Roman.

Pl. III. Zemplín, municipal office, large vessel. Photo and drawing B. Čurná Roman.

Pl. IV. Zemplín, municipal office, artefacts from the assemblage. Photo and drawing B. Čurná Roman.

Pl. V. Zemplín, municipal office, artefacts from the assemblage. Photo and drawing B. Čurná Roman.

Mgr. Martin Pristáš

Krajský pamiatkový úrad Košice

Hlavná 25

SK - 04001 Košice

martin.pristas@pamiatky.gov.sk 
